Federica Guerini*

\title{
"It sounds like the language spoken by those living by the seaside" - language attitudes towards the local Italo-romance variety of Ghanaian immigrants in Bergamo
}

\author{
https://doi.org/10.1515/ijsl-2018-0035
}

\begin{abstract}
In this article, I focus on the position of Bergamasco, the Italo-romance variety spoken in the Province of Bergamo (Northern Italy), in the linguistic repertoire of the local Ghanaian immigrant community. I argue that Ghanaian immigrants do not speak Bergamasco since the local people refrain from speaking Bergamasco to them. Bergamasco can be regarded as a we-code (Gumperz, John. 1982. Discourse Strategies. Cambridge: Cambridge University Press.) of the indigenous community, whereas Italian - in most cases, a simplified variety of standard Italian - is the default choice when communicating with immigrants. The lack of input in combination with negative attitudes and a lack of motivation to acquire the dialect triggers a self-reinforcing dynamic, making the incorporation of Bergamasco into the linguistic repertoire of Ghanaian immigrants unlikely. Excerpts from a sample of face-to-face interactions and semi-structured interviews involving a group of first-generation Ghanaian immigrants reveal that Bergamasco tends to be perceived as a sort of "secret language" deliberately used by local people to exclude immigrants and other outsiders. This stereotype originates from and is reinforced by lack of competence on the part of the migrants, but is devoid of any foundation.
\end{abstract}

Keywords: Italian, Italo-romance dialects, Ghanaian immigrants, we-code, language crossing

\section{Introduction}

Immigration from Ghana to Italy began at the end of the 1970s, when the economies of Nigeria and other West African countries with many Ghanaian labour migrants went into decline. It is an interesting example of a migration flow from a country with hardly any previous historical, linguistic, or cultural ties to the destination

*Corresponding author: Federica Guerini, Dipartimento di Lettere, Filosofia, Comunicazione, Università degli Studi di Bergamo, Bergamo, Italy, E-mail: federica.guerini@unibg.it 
state. ${ }^{1}$ As illustrated in Table 1 , the arrivals to Italy almost doubled in the last decade. $^{2}$ In January 2014, the Ghanaian citizens recorded in Italy amounted to roughly 50,000 individuals; however, given the large number of undocumented immigrants, the real figure is thought to be much higher. The slight decrease attested in 2015 and 2016 is probably due to the harsh economic crisis still affecting the Italian labour market, which may have discouraged spontaneous chain migration. At present, Ghanaians are the third-largest Sub-Saharan nationality in Italy, following Senegalese $(101,207)$ and Nigerians $(88,533)$.

Table 1: Ghanaian immigrants holding a staying permit (2003-2016).

\begin{tabular}{rrrrr}
\hline & Male & Female & Total & \% of variation \\
\hline 2003 & 14,872 & 10,996 & 25,868 & - \\
2008 & 21,635 & 16,765 & 38,400 & $+48,4$ \\
2010 & 25,092 & 19,261 & 44,353 & $+15,5$ \\
2012 & 25,155 & 19,209 & 44,364 & $+0,02$ \\
2013 & 28,260 & 20,315 & 48,575 & $+9,5$ \\
2014 & 30,243 & 20,171 & 50,414 & $+3,8$ \\
2015 & 29,640 & 18,997 & 48,637 & $-3,5$ \\
2016 & 30,497 & 17,641 & 48,138 & $-1,02$ \\
\hline
\end{tabular}

Source: ISTAT, Italian National Statistical Institute (www.demo.istat.it)

The motivation to emigrate is primarily economic, the desire to escape poverty and poor working conditions being the main reason for leaving Ghana to look for employment opportunities abroad. Most newcomers are young adults in their twenties and thirties who were born in Ghana and moved to Italy in order to improve their standard of living.

These young people arrive in Italy with a complex linguistic repertoire, including one (or more) varieties of Ghanaian English (the only official language of Ghana), Akan (Niger-Congo, Kwa) a nation-wide vehicular language, and one (or more) of the over seventy indigenous languages presently spoken in Ghana. ${ }^{3}$

1 Except from a brief period of attempted dominance in Eritrea, Ethiopia and Somalia, Italy has no colonial tradition in Sub-Saharan Africa and Italian is not part of mainstream education in Ghana.

2 Ghanaian immigrants' preference for Italy as a destination country, which parallels only that for the United Kingdom, has been recently underpinned by Marini (2015: 8).

3 The number of living languages listed by Ethnologue in 2017 amounts to 81, but the count includes European languages like English or the Ghanaian Sign Language. Due to space constraints, I will not attempt a discussion of Ghana's linguistic ecology and language contact 
Upon settling in Italy, the immigrants are expected to add to their linguistic repertoire the language(s) of the host country, i.e. Italian and/or the Italoromance variety characteristic of the region where they live.

The acquisition of Italian by different migrant groups has been studied from both language learning (e.g. Giacalone Ramat 1988, Giacalone Ramat 2003; Bernini et al. 2008; Chini 2010, Chini 2015) and sociolinguistic/language contact perspectives (e.g. Chini 2004; Bombi and Fusco 2004; Vietti 2005; Guerini 2006; Cohal 2014). Yet, little attention has been paid to how immigrants position themselves vis-à-vis the various Italo-romance dialects, to the factors at play when immigrants decide whether to acquire them, and to the motivations that may influence their choice.

In this article, I look at the position of Bergamasco, the Italo-romance variety of the Province of Bergamo, within the linguistic repertoire of the local Ghanian community. Bergamasco is not a variety of Italian, but like Italian, an autonomous language derived from spoken Latin (Section 2). Some of the factors that seem to affect the perception of the linguistic resources in the new sociolinguistic setting will be briefly discussed and a comparison between the northern and southern regions of Italy will be made on the basis of the data presently available (Section 3). In Section 4, I will discuss data from a previous study focusing on Ghanaian immigrants in Bergamo (cf. Guerini 2006, Guerini 2008). The analysis of excerpts from a sample of face-to-face interactions and semi-structured interviews involving a group of first-generation Ghanaian immigrants, combined with the author's longterm participant observation in the local community, will reveal that Ghanaian immigrants cannot speak Bergamasco since the local people refrain from speaking Bergamasco to them. In the closing section (Section 5), I argue that the interplay of three main factors -i.e. lack of input, negative attitudes and lack of motivationfeed into a self-reinforcing dynamic, which makes the incorporation of Bergamasco into the linguistic repertoire of first generation Ghanaian immigrants unlikely.

\section{Sociolinguistic background}

Italian, which is basically the result of the standardization process of the Florentine literary language developed in the fourteenth century, is the national language of Italy since 1861, when political unification was achieved. At the time, it was the mother tongue of less than three per cent of the

dynamics. For a general overview, the reader is referred to Dakubu (1988, 1997), Huber (1999), as well as to Guerini $(2006,2017)$. 
population (De Mauro 1991: 43), who spoke various Romance vernaculars, which are traditionally referred to as dialetti italo-romanzi "Italo-romance dialects".

Italo-romance dialects display sufficient structural and typological differences from Italian to be considered as separate languages: they are not social or geographical varieties of the national language, but autonomous linguistic systems that, just like Italian, developed from spoken Latin.

Without entering into details, it is easy to see that Bergamasco differs from Italian in several structural properties, which make the two of them mutually unintelligible. If we take the pro-drop parameter (e.g. Chomsky 1981: $240 \mathrm{ff}$.), for instance, Bergamasco, unlike Italian, is a non pro-drop language, which requires the overt expression of pronominal subjects even in the presence of a full nominal subject, such as the noun phrase i s-cècc "the children" in (1a), or with meteorological predicates (1c). Like other Italo-romance varieties spoken in northern Italy, Bergamasco developed a double series of subject pronouns, i.e. a tonic one and a clitic one. As (1b) illustrates, the latter (l), whose presence in a sentence is obligatory, occupy a position closer to the verb than the former (lii), which may occur (as in Italian) with a contrastive focus function (he wanted to speak, not someone else):

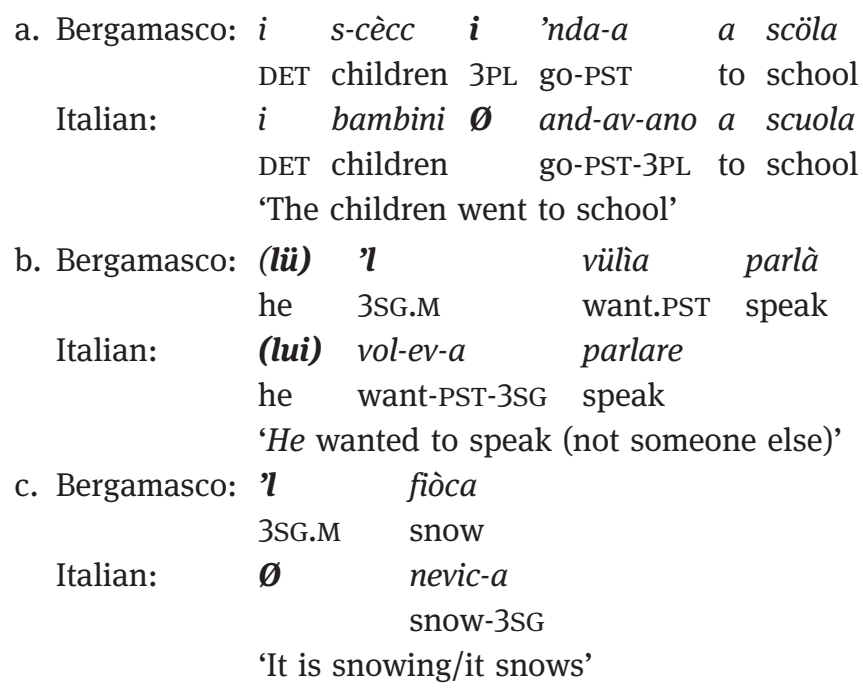

Another example is the position of the negative morpheme, which follows the main verb in Bergamasco (2a), whereas in Italian it is regularly placed before the predicate $(2 \mathrm{~b})$ : 
(2)
a. Bergamasco: $i \quad$ laùra mìa
3PL work NEG
b. Italian:

A final example concerns the expression of the direction of movement, which in Bergamasco entails the use of phrasal verbs (i.e. the combination of verbs with prepositional adverbs, as in [3a]), whereas in Italian it is realized by means of synthetic verb forms (3b) - though phrasal verbs may occasionally occur in Italian as well, especially in spoken, informal registers:
a. Bergamasco: la
'nda-a śó 'ndó-l giardì
3SG.F go-PST down to-DET garden
b. Italian:
(lei)
scend-ev-a
in giardino
go_down-PST-3SG to garden

'She went down to the garden'

Since most of the literature about the structural features of Italo-romance dialects is written in Italian, ${ }^{4}$ the typological peculiarities displayed by these Romance varieties have long remained ignored by the linguistic community. As Moretti (2007: 63) pointedly put it, "Italo-romance dialects are linguistic systems like all others. Italo-romance dialects are not linguistic systems like all others". 5

Grassi et al. (2003) describe the relationship between Italian and Italoromance dialects until the first half of the twentieth century in terms of diglossia without bilingualism: “[...] Italo-romance dialects were used in all domains of everyday life. Everybody spoke the dialects, but only a minority was also proficient in Italian, i.e. was bilingual" (Grassi et al. 2003: 31). This was true of both uneducated and educated families. Italian was used as the language of public administration and education. In ordinary, everyday conversations, the dialects prevailed.

A monolingual language policy lead to extensive language shift. Italoromance dialects were forced to compete with Italian in all domains. Italian

4 With the notable exception of the essays collected by Maiden and Parry (1997); D’Alessandro et al. (2010) and Benincà et al. (2014), among others.

5 Here and elsewhere, all translations from Italian are my own. 
is presently the native language of the majority of Italy's population, while most Italo-romance varieties are used only in informal conversations within the family domain. Italo-romance dialects are functionally subordinate to the national language, most of their speakers are bilingual in Italian, and monolingualism in an Italo-romance variety is highly stigmatized (e.g. Ruffino 2006; Guerini 2011). Unlike Italian, most Italo-romance dialects are hardly ever written, they are only occasionally heard on radio and television broadcasts, and do not occur in official or administrative documents. Hence, in many respects, their status is similar to the status shared by most of the indigenous languages spoken in the immigrants' country of origins. It is common knowledge that in order to function independently and productively in the Bergamo community, a minimum competency in Italian, but not in Bergamasco, is essential.

\section{Immigrants' attitudes towards Italo-romance dialects}

Studies investigating immigrants' attitudes to Italo-romance dialects are scarce. Yet, some information can be gathered from the sociolinguistic surveys and case studies that have been conducted so far. They reveal that immigrants' attitudes range from complete dialect acquisition in Sicily and Southern Italy, to the rejection of Italo-romance dialects in the northern and central regions of the country. For instance, Cuzzolin (2001: 103) noted that Arabophone immigrants living in Turin "perceive Italo-romance dialects as different from Italian, although they cannot explain what is the relationship between the former and the latter. Competence in Italo-romance dialects is highly stigmatized, no identity-related or integrative value is attached to it [...]" (Cuzzolin 2001: 103). A more recent survey (Biffi 2017), focusing on a sample of Moroccan women living in the Province of Bergamo, reveals that Bergamasco is commonly compared to Tamazight, the variety of Berber spoken in the immigrants' home country. As one informant put it, "Tamazight in Morocco is like Bergamasco here in Bergamo. It is a dialect, not a language. It is not our language, we are not interested in learning it" (Biffi 2017: 35). Remarks like this suggests that, though Bergamasco is perceived as a crucial component of the linguistic identity of the receiving community, dialect acquisition is not contemplated.

A similar situation emerges from a larger survey conducted by Marina Chini in 2004, which focused on immigrants from different countries of 
origins, living in the Provinces of Turin and Pavia. In this case, 414 schoolchildren and 171 adults were asked to fill in a self-evaluation questionnaire exploring, among other things, the respondents' linguistic abilities. Roughly 60\% of the school-children (Chini 2004: 138) acknowledged the presence of Italo-romance dialects in the local linguistic repertoire. However, only 3.1\% claimed to be able to understand the local dialect, and less than $1 \%$ asserted some kind of active competency (Chini 2004: 143). As for the "adult" subgroup, roughly $40 \%$ were aware of the existence of Italo-romance dialects, but no respondent reported either an active or a passive competence (Chini 2004: 251).

Villa (2014), who investigated immigrants from different countries of origins living in the Provinces of Bologna and Forli (in central Italy), maintains that, though most of her interviewees were aware of the identity-related value of the local Italo-romance varieties and could cite a few dialect words and expressions, they perceived the dialects as difficult and useless, or as an obstacle to learning the national language.

If we turn to the Southern regions of Italy, we get a very different picture. Romania (2004), for instance, argues that Albanian immigrants in Puglia are motivated to learn the local Italo-romance dialect in order to conceal their foreign origins. In a similar way, D'Agostino (2004: 206) maintains that immigrants living in Sicily and Calabria display a good competence in the local dialects. Amoruso and Scarpello (2010) note that, upon arrival in Sicily, immigrants are regularly and consistently exposed to both Italian and Sicilian in a variety of domains, a condition which triggers two parallel language acquisition processes. In a few cases, competency in the local dialect is higher than competency in Italian. These differences reflect the status of Italo-romance varieties in the local community and whether the dialect functions as we-code (Gumperz 1982) in the receiving community, which determines the quantity and quality of the linguistic input to which the immigrants are exposed as well as the receiving community's ideologies towards the use of the dialect by the newcomers.

\section{The Ghanaian immigrant community in Bergamo}

The Ghanaian community in Bergamo presently comprises about 2000 individuals. The official report of the Italian National Statistical Institute (ISTAT) put 
the number of Ghanaian immigrants in the province of Bergamo in December 2015 at 1,765; 973 men and 792 women. $^{6}$

The following observations are based on face-to-face interactions and semi-structured interviews (a total of roughly 30 hours of recordings) (cf. Guerini 2006, Guerini 2008). In combination with long-term participant observation, the data suggest that Ghanaian immigrants know that Bergamasco is part of the local linguistic repertoire. The dialect is generally viewed as a crucial component of the linguistic identity of the host community, and tends to be associated with the values - productiveness, determination and industriousness - traditionally attributed to its members (cf. Guerini 2006: 62). Yet, Ghanaian immigrants cannot speak Bergamasco since the local people do not speak Bergamasco with them. In fact, Bergamasco can be regarded as a we-code of the local community, whereas Italian -in most cases, a simplified variety of Italian - is the default choice when communicating with (perceived) outsiders.

Negative attitudes towards the local dialect result from lack of proficiency, combined with the intimacy and solidarity connotations carried by Bergamasco as an in-group language and identity marker. Some informants perceived Bergamasco as a sort of secret language deliberately used by local people to exclude immigrants and other outsiders, ${ }^{7}$ a stereotype that originates from and is reinforced by the lack of competence, although it is devoid of any foundation.

The immigrant quoted in extract (4), for instance, misinterprets the behaviour of the local people, who switch from Bergamasco to Italian in his presence, and concludes that Bergamasco is employed to exclude immigrants from the ongoing conversation (“... if they don't want you to understand, then they speak Bergamasco, so that you don't understand”) ${ }^{8}$ :

6 See http://demo.istat.it/str2015/index.html (last accessed in May 2017).

7 The same belief, i.e. that the local Italo-romance variety is adopted in order to exclude immigrants from the on-going conversation, is reported also by Villa (2014: 46-47).

8 In all the extracts quoted in the present article the researcher is indicated as $\mid$ Int $\mid$ (Interviewer), while the various informants are signaled by the first letter of their name. The following print styles have been adopted in order to distinguish the different languages employed by the interactants: Roman (English), italics (Italian), bold (Akan), bold italics (Bergamasco). The symbol = indicates a lack of interval between the end of a speaker's utterance and the following turn. 
(4) \Int $\backslash$ and what do you think of the people who can speak only the Bergamasco dialect?

$\backslash \mathrm{Ch} \backslash$ only the dialect?

\Int\ yes, and not the Italian language

$\backslash \mathrm{Ch} \backslash$ well, I don't know if they do that because, wherever I go here in Bergamo, if they [i.e. the local people] speak Bergamasco, they change $\mathrm{it}=$

\Int

$$
=\mathrm{I} \text { see }=
$$

$$
\text { =and they }
$$

speak Italian, but if they don't want you to understand, then they speak Bergamasco, so that you don't understand!

The local population use the language alternation strategy Ch describes in the presence of any foreigner, including tourists coming from other parts of Italy, representing a form of language accommodation. It is a conversational strategy aimed at including outsiders in the ongoing conversation, rather than preventing them from acquiring the local dialect. The poor competency of the younger generations, resulting from the language shift process that I described in the previous section, prevents the use of Bergamasco even when addressing local children and teenagers, whose involvement in a conversation regularly triggers a switch to Italian. ${ }^{9}$ In other words, the community's current appropriateness norms restrict the use of Bergamasco to interactions involving competent, adult members of the local society.

In extract (5) we have a similar example: the interviewee is convinced that local people "do not speak Bergamasco to make you understand, but only to insult you", a stereotype fuelled by the lack of competency, as the informant readily acknowledges. This confirms the interrelation between attitudes and proficiency already evinced by Baker (1992: 44): the higher the proficiency in a language, the more favourable the attitudes.

9 A behaviour that I had the opportunity to witness on several occasions, and which is reported also by Moretti (1990) in the Ticino area (southern Switzerland) and by Giacalone Ramat (1995: 50). 
(5) \Int $\backslash$ and when you go shopping or you go around in Clusone and the local people speak to you, your impression is that the language they use is simpler, to make you understand, or difficult ... or maybe simply normal?

$|F\rangle$ if we are on the street and they speak Italian and we understand, we will be happy, but if they speak Bergamasco ... because they don't speak Bergamasco to make you understand, when they speak Bergamasco it's only to insult you=

$\mid$ Int $\backslash=$ I see $=$

$|F| \quad=$ the way the speak=

|Int $\backslash \quad=$ I see ... so you do not understand Bergamasco, do you?

$\backslash F \backslash \quad$ no

The episode described in the following extract (6) is emblematic of the choice of Bergamasco as the preferred means of in-group communication. The main consequence of this state of affairs is that the immigrants' competency remains limited to a few words and other stereotyped expressions, such as greetings, discourse markers and leave-taking formulas, drawn from occasionally overheard conversations:

(6) IZ $\backslash$ I work with a family/ I work with a family and when they are quarreling, they speak only Bergamasco! ... Then, later, the man asks me, signora Zita, did you understand what we are saying? or did you hear what my wife said? I would say, no. And he [would say], it is good that you did not understand, it is a very bad word that my wife has told me! [laughing]

Attitudes towards Bergamasco, however, are ambivalent, not only as a result of the immigrants' lack of input, but also because, in present-day Italy, Italo-romance dialects enjoy little prestige. Their use is stigmatized in most formal and institutional domains and tends to be associated with backwardness, provincialism and lack of formal education. ${ }^{10}$ The Ghanaian quoted in extract (7), for instance, depicts the "prototypical" native speaker of Bergamasco as a

10 The existence of ambivalent attitudes towards the Italo-romance varieties spoken in Italy is well-documented in the literature; for a general overview, the reader is referred to Sobrero and Miglietta (2006) and Ruffino (2006). See also Guerini (2011). 
shepherd, who lives in the mountains with sheep and goats, and who is likely to be ridiculed in mainstream society.

(7) $\mid F \backslash \quad[. .$.$] if you meet someone at the Comune, who has been on the$ mountains with goats and animals=

\Int \}

=un pastore?

'A shepherd?'

$\mid F \backslash \quad$ yeah, so, if he comes to town, you can't understand a word of what he says, he would speak pure Bergamasco ... so the people would laugh at him, they would say that he is/ he is $=$

$\backslash$ Int $\backslash \quad=$ a traditional man?=

$\mid \mathrm{F} \backslash$

$=\mathrm{a}$ traditional man from the village, because he doesn't speak Italian! Only Bergamasco, and the pure Bergamasco!

Another factor contributing to the prevailing lack of competence in Bergamasco is the immigrants' instrumental orientation to language learning. The perceived practical and economic value of proficiency in a foreign language is the principal motivation for learning it. As Fishman pointedly put it, "languages are never acquired for their own sake. They are acquired as keys to other things that are desired" (Fishman 1989: 242). So - as the speaker in extract (8) observes- why should they learn a more or less useless language like Bergamasco, which can be used in Bergamo only?

(8) $\quad$ Int $\backslash \quad[. .$.$] so you don't understand [the dialect], but would you like to$ learn it, to speak Bergamasco?

\C\ [Shaking his head] No

\Int \you are not interested, I see ... As for the Italian language, would you like to learn it?=

$\mid C \backslash \quad$ =yes, because Bergamasco, if you learn it and you go to Brescia, they don't speak it, beyond Brescia=

\Int\=it's too limited

$\backslash \mathrm{C} \backslash$ yes! If you go to Seriate, da Seriate in poi it's another provincia! 'If you go to Seriate, from Seriate onwards, it's another province! (i.e. a different Italo-romance variety is spoken)' 
Attitudes like the one expressed above are commonly observed in language shift situations (Denison 1977), and are likely to be influenced by the general attitudes prevalent in the host community. Italian, which can provide greater economic and professional benefits, is the "proper language" (as the informant in extract [9] observes), the one which ought to be learned first, whereas the utility of Bergamasco is limited to the province of Bergamo:

(9) \Int $\backslash$ and ... would you like to learn the local dialect, Bergamasco?

$\backslash \mathrm{Gr} \backslash$ I want to learn the proper language first!

\Int $\backslash$ ah, ok ... so, the Italian language first, and later the dialect=

$\mid \mathrm{Gr} \backslash$

$=\mathrm{I} \quad$ want

to learn the proper one, because Bergamasco is only in Bergamo/ is limited=

\Int $\quad=$ it's

limited, I see $=$

$\mid \mathrm{Gr} \backslash \quad=$ while the other one [i.e. Italian], I can use it everywhere

In a similar way, the role of English as an international lingua franca places it at the highest level of the language hierarchy. English is generally perceived as the only language worth being literate in, though the necessity to obtain a certain proficiency in Italian is also acknowledged. The latter, however, tends to be viewed as a disadvantage originating from the local people's reluctance to learn an international language like English. The utility of Italian vanishes as soon as one enters Rome's international airport (cf. extract 10), as this Ghanaian woman observes:

(10) \Int \ do you believe that learning the Italian language is necessary?

$\backslash \mathrm{O} \backslash$ sometimes is necessar, but=

$\backslash \mathrm{Gr} \backslash \quad$ =ose sen?

'What did she say?'

$\backslash 0 \backslash$ Italian language ye necessary anaa?

'Is the Italian language necessary or not?'

$\backslash \mathrm{Gr} \backslash$ wosi mu Fiumicino na asa!

'If you leave Fiumicino (Rome’s international airport), that's all!'

A final point concerns the fact that ambivalent attitudes towards the local dialect are often displayed by using it mockingly in order to express one's distance from the "prototypical" dialect speaker - perceived in a simplified, 
stereotyped way - and play with an identity other than one's own. This kind of linguistic behaviour has been described as "language crossing", "a form of codeswitching" that entails "the use of language varieties associated with social or ethnic groups the speaker does not normally 'belong' to” (Rampton 1995: 14).

In extract (11), the linguistic portrayal of the dialect speaker is realized not only through the insertion of a stereotyped utterance in Bergamasco ("Eat polenta, eat polenta!"), ${ }^{11}$ but also by drawing a parallel between the local dialect and a tone language, ostensibly spoken by "those living at the seaside", presumably in Ghana:

(11) \Int $\backslash$ can you tell the difference [between Italian and Bergamasco]?

$\backslash \mathrm{I} \backslash \quad$ yes, yes ... Bergamasco is/ they/ that language they use has a huge tone, you know, mangià polenta, mangià polenta! [laughing] cte se mpoanofos!

'... eat polenta, eat polenta! It sounds like [the language spoken by] those living at the seaside!'

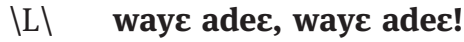

'You are right, you are right!'

$\backslash \mathrm{I} \backslash \quad$ they speak like that, oh!

$\backslash \mathrm{L} \backslash$ mente, mente!

'I don't understand, I don't understand!'

$\backslash I \backslash \quad$ there is difference!

Lydia, the other Ghanaian involved in the interaction, supports the analogy: "You are right, you are right!", although she acknowledges her lack of competence ("I don't understand [Bergamasco]"). Note also the repetition of thirdperson plural pronouns ("Bergamasco is/they/that language they use ... they speak like that!”), a choice expressing the immigrant's disaffiliation from Bergamasco and its speakers.

This kind of quoting is a form of switching largely independent of language fluency, in that it may be performed effectively by speakers knowing just a few words or ritual expressions in the language in question. Extract (12) is from an interview with Rita, a Ghanaian woman in her forties who has been living in Bergamo for roughly fifteen years, and Lydia a younger immigrant, who has just arrived in Italy and has established only limited contacts with the local community:

11 Polenta is the name of a local staple made from maize flour and water. 
(12) $\mid$ Int $\backslash$ and do you understand the Bergamasco dialect?

$\backslash L \backslash \quad$ no

Int $\backslash$ and, Rita, can you understand it?

$\mid R \backslash \quad$ [laughing] Pòta ma

'Sure, but'

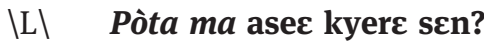

'What is the meaning of Pòta ma?'

$\backslash \mathrm{R} \backslash \quad$ Pòta ma ... stà sö! [laughing]

'Sure but ... stay upright!'

\L Pòta ma عte sen?

'... what does it mean?'

$\mid R \backslash$ Obi ka asem a wontumi nkyere asec, pòta ma, pòta ma! [laughing]

'If someone says something you will not be able to explain, pòta ma, pòta ma!'

When questioned about her ability to understand the local dialect, Rita makes repeatedly use of short stereotyped expressions in a language of which she apparently knows only a few words. In this context, the choice of Bergamasco is not motivated by the desire to sound like a member of the local community. As the speaker's laugher suggests, it is intended as a parody of the local community members: Rita employs a language other than her own, to which she has been at least occasionally exposed, in order to signal her disaffiliation from the social or ethnic group traditionally associated with the language in question. In this sense, we can say that Bergamasco is experienced as a marker of local identity, but it is not seen as a means of social integration.

\section{Discussion}

The above analysis suggests that Ghanaian immigrants do not speak Bergamasco for three reasons:

- Lack of input: Bergamasco functions as a we-code of the receiving community, whereas Italian is the unmarked choice when addressing outsiders.

- Negative attitudes: monolingualism in an Italo-romance dialect is associated with lack of education, linguistic deprivation and low socio-economic status. Even L1-speakers of Bergamasco, therefore, harbour negative attitudes and 
feelings of linguistic insecurity. ${ }^{12}$ These attitudes influence newcomers' perception of the linguistic choices available to them in their new sociolinguistic setting;

- Lack of motivation to learn the dialect, owing to an instrumental attitude to language learning and the low status and lack of prestige of Bergamasco.

The interplay of these factors triggers a self-reinforcing dynamic, which favours the maintenance of the status quo.

It is important to note that my survey took into account only first-generation immigrants: language attitudes and competences among second and thirdgeneration immigrants may differ considerably, as the studies carried out in other European countries attest. In Italy, a second generation of immigrants is still in its infancy. The younger immigrants belong to the so-called 1.5 generation (cf. Lo 1999), consisting of immigrants who were born in Ghana and came to Italy with their parents at a very young age, but received their main socialization in Italy and are presently attending Italian schools (cf. Guerini 2017).

Thanks to school attendance and under the pressure of the communication needs of the labour market, the migrants' proficiency in Italian is bound to improve. By contrast, their future proficiency in Bergamasco is more difficult to predict. General competence in Bergamasco, as in other Italo-romance dialects is declining. In small rural communities, where proficiency in Bergamasco is higher and the vernacular still functions as a marker of local identity, developing a certain competence in the dialect may be read as a positive move towards integration. Ghanaian immigrants' overall favourable orientation towards the values traditionally cherished in the receiving society may eventually win them membership in the local community and hence, access to Bergamasco.

On the other hand, it is interesting to note how the attitudes shared by a relatively small immigrant group underpin the prestige and status hierarchies within the receiving community's repertoire: Ghanaian immigrants' rejection of Bergamasco is an indirect sign of its gradual but steady decline. This opens new possibilities for future research on language shift and language maintenance patterns in multilingual environments by drawing attention to the dynamics affecting the perception of the indigenous languages by the various diasporic groups.

Acknowledgements: The present article is the revised version of a contribution originally presented to the "Dialects and migration in Europe" panel at ICLaVE 9 (Malaga, June 6-9, 2017), organized by Peter Auer and Unn Røyneland. My

12 Cf. Guerini (2011: 119-120). 
thanks are due to the panel organizers, who offered me the opportunity to engage in an invaluable discussion with other scholars investigating immigration and its impact on language attitudes and choices, as well as to the panel discussants and audience, whose feedback greatly improved the quality of this work. I am also grateful to Florian Coulmas for his comments and his advice on a first draft of this article. Needless to say, any shortcomings contained in these pages are my sole responsibility.

\section{References}

Amoruso, Chiara \& Iolanda Scarpello. 2010. Il dialetto nei discorsi degli immigrati: intrecci di sistema e scelte d'uso. In Maria Iliescu, Heidi Siller-Runggaldier \& Paul Danler (eds.), Actes du XXVe Congrès International de Linguistique et Philologie Romanes, 4-12. Berlin: De Gruyter.

Baker, Colin. 1992. Attitudes and language. Clevedon: Multilingual Matters.

Benincà, Paola, Adam Ledgeway \& Nigel Vincent (eds.). 2014. Diachrony and dialects. Grammatical change in the dialects of Italy. Oxford: Oxford University Press.

Bernini, Giuliano, Spreafico Lorenzo \& Ada Valentini. 2008. Competenze lessicali e discorsive nell'acquisizione di lingue seconde. Perugia: Guerra.

Biffi, Giulia. 2017. Repertori linguistici complessi in contesto migratorio: uno studio di caso su un campione di donne di origine africana. Unpublished Master Degree dissertation, University of Bergamo, Dept. of Letter, Philosophy, Communication.

Bombi, Raffaella \& Fabiana Fusco (eds.). 2004. Città plurilingui. Lingue e culture a confronto in situazioni urbane. Udine: Forum.

Chini, Marina (a cura di). 2004. Plurilinguismo e immigrazione in Italia. Un'indagine sociolinguistica a Pavia e Torino. Milano: FrancoAngeli.

Chini, Marina (ed.). 2010. Topic, information structure and language acquisition. Milano: FrancoAngeli.

Chini, Marina (ed.). 2015. Il parlato in italiano L2: aspetti pragmatici e prosodici. Milano: FrancoAngeli.

Chomsky, Noam. 1981. Lectures on government and binding. Dordrecht: Foris.

Cohal, Alexandru L. 2014. Mutamenti nel romeno di immigrati in Italia. Milano: FrancoAngeli.

Cuzzolin, Pierluigi. 2001. Percezione del contatto di lingue: arabo classico, arabo moderno, italiano, dialetto. In Massimo Vedovelli, Stefania Massara \& Anna Giacalone Ramat (eds.), Lingue e culture in contatto. L'italiano come L2 per gli arabofoni, 89-107. Milano: FrancoAngeli.

D’Agostino, Mari. 2004. Immigrati a Palermo. Contatti e/o conflitti linguistici e immagini urbane. In Raffaella Bombi \& Fabiana Fusco (eds.), Città plurilingui. Lingue e culture a confronto in situazioni urbane, 191-210. Udine: Forum.

D’Alessandro, Roberta, Adam Ledgeway \& Ian Roberts (eds.). 2010. Syntactic variation. The dialects of Italy. Cambridge: Cambridge University Press. 
Dakubu, Mary Esther Kropp (ed.). 1988. The languages of Ghana. London, UK: Kegan Paul International.

Dakubu, Mary Esther Kropp (ed.). 1997. English in Ghana. Accra (Ghana): A publication of the Ghana English Studies Association.

De Mauro, Tullio. 1991. Storia linguistica dell'Italia unita. Roma-Bari: Laterza.

Denison, Norman. 1977. Language death or language suicide? International Journal of the Sociology of Language 12. 13-22.

Fishman, Joshua. 1989. Language and ethnicity in minority sociolinguistic perspective. Clevedon: Multilingual Matters.

Giacalone Ramat, Anna (ed.). 1988. L'italiano tra le altre lingue. Strategie di acquisizione. Bologna: Il Mulino.

Giacalone Ramat, Anna. 1995. Code-switching in the context of dialect/standard language relations. In Leslie Milroy \& Peter Muysken (eds.), One speaker, two languages. crossdisciplinary perspectives on code-switching, 45-67. Cambridge: Cambridge University Press.

Giacalone Ramat, Anna (ed.). 2003. Verso l'italiano. Percorsi e strategie di acquisizione. Roma: Carocci.

Grassi, Corrado, Sobrero Alberto \& Tullio Telmon. 2003. Introduzione alla dialettologia italiana. Laterza: Roma-Bari.

Guerini, Federica. 2006. Language alternation strategies in multilingual settings. A case study: Ghanaian immigrants in Northern Italy. Bern: Peter Lang.

Guerini, Federica. 2008. Atteggiamenti e consapevolezza linguistica in contesto migratorio: qualche osservazione sugli immigrati ghanesi a Bergamo. In Cecilia Andorno, Gaetano Berruto, Brincat Joseph \& Sandro Caruana (eds.), Lingua, cultura e cittadinanza in contesti migratori. Europa e area mediterranea, 113-163. Perugia: Guerra.

Guerini, Federica. 2011. Language policy and ideology in Italy. International Journal of the Sociology of Language 210. 109-126.

Guerini, Federica. 2017. English and the Ghanaian diaspora in Northern Italy. In Boggio Cecilia \& Molino Alessandra (eds.), English in Italy: linguistic, educational and professional challenges, 223-236. Milano: FrancoAngeli.

Gumperz, John. 1982. Discourse strategies. Cambridge: Cambridge University Press.

Huber, Magnus. 1999. Ghanaian Pidgin English in its West African context. Amsterdam, The Netherland: Benjamins.

Lo, Adrienne. 1999. Codeswitching, speech community membership, and the construction of ethnic identity. Journal of Sociolinguistics 3(4). 461-479.

Maiden, Martin \& Mair Parry (eds.). 1997. The dialects of Italy. London and New York: Routledge.

Marini, Francesco. 2015. Co-sviluppo e integrazione. Le associazioni ghanesi in Italia e nel Regno Unito. Milano: FrancoAngeli.

Moretti, Bruno. 1990. Varietà del repertorio linguistico e fenomeni lessicali nel baby talk. RID, Rivista Italiana di Dialettologia 14. 139-155.

Moretti, Bruno. 2007. Una dialettologia oltre i dialetti? In Gianmario Raimondi \& Luisa Revelli (eds.), La dialectologie aujourd'hui. Atti del convegno internazionale "Dove va la dialettologia", 61-67. Alessandria: Edizioni dell'Orso.

Rampton, Ben. 1995. Crossing: Language and ethnicity among adolescents. London/New York: Longman. 
Romania, Vincenzo. 2004. Farsi passare per italiani. Strategie di mimetismo sociale. Roma: Carocci.

Ruffino, Giovanni. 2006. L'indialetto ha la faccia scura. Palermo: Sellerio.

Sobrero, Alberto A. \& Annarita Miglietta (eds.). 2006. Lingua e dialetto nell'Italia del Duemila. Galatina: Congedo.

Vietti, Alessandro. 2005. Come gli immigrati cambiano l'italiano. L'italiano di peruviani come varietà etnica. Milano: FrancoAngeli.

Villa, Valeria. 2014. Dinamiche di contatto linguistico nelle narrazioni di immigrati: dialetti e varietà regionali. In Anna De Meo, Mari D’Agostino, Gabriele lannàccaro \& Lorenzo Spreafico (eds.), Varietà dei contesti di apprendimento linguistico, 43-58. Milano: Officinaventuno. 